\title{
A review- bioremediation of oil sludge contaminated soil
}

\author{
Riju Chandra Saha ${ }^{1,}$, Auchib Reza ${ }^{1}$, Muhammad Sakib Hasan ${ }^{2}$ and Piash Saha ${ }^{2}$ \\ ${ }^{1}$ MEng. Student, Memorial University of Newfoundland, NL, Canada \\ ${ }^{2}$ B.Sc. Khulna University of Engineering \& Technology, Khulna, Bangladesh
}

\begin{abstract}
Petroleum oil as a vast source of energy widely used in the whole world in several sectors especially in industry and transportation. The leakage or contamination of oil from pipeline, tank, and industry as a form of oil sludge with soil can produce major environmental and health hazard. Bioremediation is one of the most economical and environmentally safe technology to prevent this contamination though it takes longer time. This paper reviews the basic processes involved in bioremediation, types and the factors affecting it. This study includes some previously adopted different bioremediation methods varies with different process material such as refinery treatment sludge, sewage sludge, microbial organism, bulking agents and different chemical additives. The comparison of these methods is presented in respect of the removal efficiency of an entire process as well as the TPH (Total Petroleum Hydrocarbon), aliphatic, aromatic, resins, asphaltene fraction of oil sludge within the different period of time.
\end{abstract}

\section{Introduction}

The importance of petroleum oil is increased day by day as it is used as major raw material to provide the energy and heating facility for running the huge number of industries around the world [1]. The consumption of petroleum oil was $93.60 * 106$ barrels per day in 2015 which may be increased about $38 \%$ at the end of 2040 [2, 3]. This petroleum oil is a composition of aliphatic hydrocarbon, aromatics, resin, asphaltene and other organic and organometallic compound [4]. Environment is seriously contaminated with petroleum products due to tanker accidents, storage tank ruptures, pipeline leaks, transport accidents, offshore and onshore petroleum industry activities etc. [5-7]. These petroleum products adversely affect the ecosystems and biological activity by changing the parameter such as $\mathrm{pH}$, moisture content and aeration level of soil and introduce toxicity [8, 9]. Petroleum hydrocarbons exist in $60 \%$ of contaminated sites of whole Canada causing toxicity propagation in environment, continuation of soil degradation by affecting water and nutrient retention $[10,11]$. There are some physical and chemical method such as landfilling, incineration to remove hydrocarbon contaminants. These methods often produce toxic chemical affecting the physicochemical properties of soil [4]. Bioremediation has the cost effective, eco-friendly and sustainability advantages comparable to these method [12].The aim of this study is to give an overview of bioremediation technology highlighting the factors on which it depends and comparison of different strategies adopted by different researchers for this technology.

\section{Overview of bioremediation technology}

Bioremediation of contaminated soil is defined as the use of living organism (mainly bacteria, fungi, algae) to make environment free from toxicity of contaminant through transformation, degradation and mineralization of the contaminants to less harmful compound [13, 14]. There are three basic processes involved in this technology. These are bio-transformation which convert contaminant components into less or non-hazardous products, biodegradation which produces smaller organic or inorganic molecules from organic substances and finally mineralization which involves entire breakdown of organic materials into inorganic compounds such as $\mathrm{CO}_{2}$ or $\mathrm{H}_{2} \mathrm{O}$ [15]. Each of these process can occur at contaminant site (in situ) or out of contaminant site (ex situ) as well as aerobic (with oxygen) and anaerobic (without oxygen) [16]. In situ bioremediation involves the treatment of organic pollutants under natural conditions at original contaminated sites without relocation [7, 14].Whereas Ex situ bioremediation excavation and transportation of pollutants from original contaminated site to be treated elsewhere to maintain the proper conditions of the bioremediation process more easily [14]. Though ex situ bioremediation is faster than in situ, due to relocation of pollutants it has increased cost and the chance of direct exposure of toxicity to public generally worker [7]. Fig. 1 represents the types of bioremediation.

\footnotetext{
Corresponding author: rcsaha@mun.ca
} 


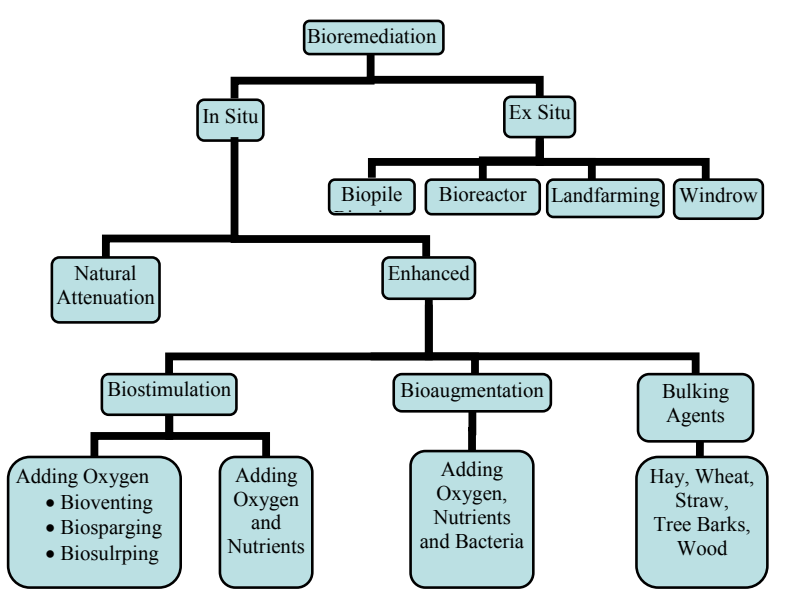

Fig. 1 Schematic diagram for types of bioremediation $[10,20]$.

\section{Factors affecting bioremediation technology}

\subsection{Nutrients}

The acceleration and growth of microbial organism such as bacteria and fungi depends on carbon nutrient elements such as Nitrogen and Phosphorus, an electron acceptor and organic compound that supplies carbon and energy $[17,18]$. The growth of the microorganism is prevented if there is shortage of organic and inorganic compounds such as nitrates, sulphates, carbon dioxide, ferric iron, amino acids, vitamins and the metabolism of microorganisms will occur [14]. Microorganisms facilitate degradation of oil sludge depending on some certain forms of nitrogen and phosphorus $\left(\mathrm{NH}_{3}, \mathrm{NO}^{3-}\right.$, $\mathrm{NO}^{2-}$, organic nitrogen and orthophosphate such as $\mathrm{KNO}_{3}$, $\mathrm{NaNO}_{3}, \quad \mathrm{NH}_{3} \mathrm{NO}_{3}, \quad \mathrm{~K}_{2} \mathrm{HPO}_{4}$ and $\left.\mathrm{MgNH}_{4} \mathrm{PO}_{4}\right)$ and nutrients in the form of fertilizers, slow release and oleophilic are added to meet this requirement [19].

\subsection{Effect of $\mathrm{pH}$}

Microorganisms and enzymes have $\mathrm{pH}$ dependency behaviour [21]. In most of cases microbial organism perform degradation activities at optimum nearly at neutral $\mathrm{pH}$ between 6 and 9 [22, 23]. In some cases, liming is introduced to transform from acidic to alkaline state to facilitate bacterial more than fungal growth to avoid mutagenic intermediates produced by fungal decomposition of PAHs [14].

\subsection{Temperature}

There is direct effect of temperature on the properties of oil hydrocarbon in soil. Generally this hydrocarbon pollutant exists in soil with longer period of time at low temperature [21]. The viscosity is increased with decrease in temperature whereas the solubility in water and volatility is reduced which negatively affect the transformation of long chain n-alkanes from solid phase to water phase causing delaying the oil sludge biodegradation [24]. Though there is a variety range of temperatures for effective biodegradation of hydrocarbon it is found to be optimum between 30 to $40^{\circ} \mathrm{C}$ [14].

\subsection{Water activity}

Biodegradation rates are highly influenced by the microbial growth and their biochemical and enzymatic activities which are directly related to amount of water in soil. Sufficient moisture content is needed for transportation of both soluble pollutant molecules across the microbial cell membrane through absorption and final degraded products [7, $14 \& 21]$. Optimal bioactivity for effective aerobic bioremediation occurs when moisture is between $30 \%$ and $80 \%$ of the saturation (moisture holding capacity) available for plant usage [10]. Microbial activity becomes less effective when the moisture content is below $10 \%[10,25]$. However there is waterlogging problem if water holding capacity of soil rises above the optimal limit which develops anoxic condition and badly affects bioremediation rates [14].

\subsection{Oxygen}

Oxygen is mostly important for aerobic biodegradation which is the more effective than anaerobic condition because the biodegradation rates in that condition is limited to halogenated aromatics compounds [26]. The molecular oxygen is needed for use of oxygenase to degrade the oil sludge component and higher efficiency is achieved with sufficient availability of oxygen. This means that, the presence and concentration of oxygen is important in such process [27]. Also, lack of aeration, in the system may be a rate-limiting parameter in the biodegradation and catabolism of hydrocarbons by bacteria and fungi [23].

\subsection{Texture, hydraulic conductivity and permeability}

These three interrelated geotechnical properties of soil affect the supply of nutrient, oxygen \& contaminants which in return affect the microbial activity and biodegradation of pollutant [10]. .Low permeability fractured rocks are inefficient to supply the flushing solutions to the contaminants and flushed with surfactants and co-solvents [10]. Soil with hydraulic conductivity larger than $10-4 \mathrm{~cm} / \mathrm{s}$ is found to be sufficient for transport of nutrients and pollutants [28]. Finely texture soils (greater amount clay minerals) of low permeability will supply less nutrients and oxygen to microorganisms and due to their high surface area and chemical reactivity will cause biofouling as because soil pore spaces are plugged with microbial cells [29].Sand and silt particles have less effect on the supply of nutrients and oxygen as they are less reactive chemically due to their smaller surface area [10]. 


\subsection{Salinity}

It was found from different studies that salinity maintains a positive dependency with rates of mineralization of polycyclic aromatic hydrocarbons [30]. It is also noted that hyper salinity with high temperature will decrease microbial metabolic rates, growth and their products [31].

\section{Material Used}

All of these types shown in Fig. 1 adopt the mechanism to stimulate the microbial community for degrading the contaminants of soil. Materials used to assist in bioremediation are generally based on these types for accumulating the growth of microbial community. Table I summarizes some materials used in different bioremediation methods by some researchers. Some uses addition of nutrients such as slow lease fertilizer in biostimulation to increase the efficiency of biodegradation by stimulating microbial growth [32]. Bulking agent such as wheat bran, wood chips, sawdust, leaves, hay, shredded rubber tires, cotton stalks, rice straw are used to increase the oxygen diffusion by increasing soil porosity and decreasing the soil bulk density and it facilitates microbial activity [33]. Inorganic salts with commercial fertilizers, manure and sewage sludge have an effect to increase the removal efficiency of hydrocarbons in soil up to two times [13].

\section{Microbial communities and activities}

Microbial community characterization with a combination of a single bacterial strain or in a syntrophic bacterial consortium, of selective degrading abilities can provide successful mechanism to biodegrade in a given environment [34]. Soil microbial activities are found to be negatively affected if hydrocarbon levels go beyond $10 \%$ [35]. Bio-surfactants an important agents produced by bacteria have the ability to emulsify petroleum hydrocarbon in oil sludge by increasing the surface area of the substrates and their solubility will be increased so that they can be easily biodegradable to bacteria and fungi [14]. These bio-surfactants extracted by bacteria can enhance hydrocarbon catabolism with bulking agents and has the advantage of being more cost effective, natural and non-toxic than chemical surfactants in biodegradation of petroleum hydrocarbons [36].

\section{Comparison}

Table 1 represents the different bioremediation strategies of soil contaminated with different pollutants such as crude oil, diesel oil, petroleum, sludge from different oil industry which performed by different researcher. It also shows that different materials such as different bacterial community, bulking agents, nutrients in the form of fertilizer and some chemical additives were used by different methods. All these method were run for various duration from 38 days to 1 year and consequently achieve removal efficiencies from $58 \%$ to $99.9 \%$ with different contaminant concentration.
Table 1. Different Bioremediation Strategies of Oil Contaminated Soil.

\begin{tabular}{|c|c|c|c|c|}
\hline $\begin{array}{c}\text { Material or } \\
\text { Additive } \\
\text { Used }\end{array}$ & $\begin{array}{l}\text { Oil Contaminant } \\
\& \text { Concentration }\end{array}$ & $\begin{array}{l}\text { Maximum } \\
\text { Duration }\end{array}$ & $\begin{array}{c}\text { Maximum } \\
\text { Removal } \\
\text { Efficiency } \\
\end{array}$ & $\begin{array}{l}\text { Sour } \\
\text { ce }\end{array}$ \\
\hline $\begin{array}{l}\text { Two } \\
\text { hydrocarbo } \\
\text { n clastic } \\
\text { bacterial } \\
\text { isolates }\end{array}$ & $\begin{array}{l}\text { Crude oil tank } \\
\text { bottom sludge } \\
\text { (COTBS), } 30.7 \\
\text { g/kg }\end{array}$ & 90-days & $96-97 \%$ & {$[3]$} \\
\hline $\begin{array}{l}\text { Nutrients as } \\
\text { phosphate } \\
\text { and nitrate } \\
\text { salts }\end{array}$ & $\begin{array}{l}\text { Maroon oil } \\
\text { reservoir tank } \\
\text { sludge, } 5 \% \mathrm{w} / \mathrm{w}\end{array}$ & 365-days & $\begin{array}{l}\text { TPH } 34 \% \text {, } \\
\text { Aromatic } \\
\text { Fraction } 43 \% \text {, } \\
\text { Aliphatic } \\
\text { Fraction } 64 \% \text {, } \\
\text { Asphaltene 4\%, } \\
\text { Resin } 6 \%\end{array}$ & {$[4]$} \\
\hline $\begin{array}{l}\text { Nutrients, } \\
\text { inoculum } \\
\text { and bulking } \\
\text { agents }\end{array}$ & Diesel, $1 \% \mathrm{v} / \mathrm{v}$ & 90-days & $96.6 \%$ & {$[10]$} \\
\hline $\begin{array}{l}\text { Landfarmin } \\
\mathrm{g} \text { with } \\
\text { cotton } \\
\text { stalks }\end{array}$ & $\begin{array}{l}\text { Shengli oil field } \\
\text { open storage } \\
\text { sludge, } 12.57 \\
\mathrm{mg} / \mathrm{g}\end{array}$ & 1170-days & $\begin{array}{l}\text { TPH } 64.8 \%, \\
\text { Aromatic } \\
\text { Fraction } 85.5 \% \text {, } \\
\text { Aliphatic } \\
\text { Fraction } 90 \%\end{array}$ & {$[37]$} \\
\hline $\begin{array}{l}\text { Bacterial } \\
\text { consortium, } \\
\text { inorganic } \\
\text { nutrients, } \\
\text { compost } \\
\text { and a } \\
\text { bulking } \\
\text { agent of } \\
\text { wheat bran }\end{array}$ & $\begin{array}{l}\text { Petroleum } \\
\text { refinery Sludge, } \\
5 \% \mathrm{w} / \mathrm{w}\end{array}$ & 90-days & $72 \%$ & {$[38]$} \\
\hline $\begin{array}{l}\text { Bacterial } \\
\text { consortium, } \\
\text { nutrients } \\
\text { mixture }\end{array}$ & $\begin{array}{l}\text { Refinery oil } \\
\text { sludge, } 18 \% \mathrm{w} / \mathrm{w}\end{array}$ & 365-days & $\begin{array}{l}\text { TPH } 89.7 \% \text {, } \\
\text { Aromatic } \\
\text { Fraction } 94.1 \% \text {, } \\
\text { Aliphatic } \\
\text { Fraction } 95.1 \% \text {, } \\
\text { Asphaltene }+ \\
\text { NSO } 63.5 \%\end{array}$ & [39] \\
\hline $\begin{array}{l}\text { Sewage } \\
\text { sludge, } \\
\text { chemical } \\
\text { additives }\end{array}$ & $\begin{array}{l}\text { Diesel fuel, } 30 \\
\mathrm{~g} / \mathrm{kg} \& \text { Black oil, } \\
30 \mathrm{~g} / \mathrm{kg}\end{array}$ & 120-days & $90 \% \& 63 \%$ & {$[40]$} \\
\hline $\begin{array}{l}\text { Manure } \\
\text { with } \\
\text { indigenous } \\
\text { microbes } \\
\text { and rice } \\
\text { straw }\end{array}$ & $\begin{array}{l}\text { Petroleum, } 519 \\
\mathrm{~g} / \mathrm{kg}\end{array}$ & 360-days & $\begin{array}{l}\text { TPH } 58.2 \% \text {, } \\
\text { Aromatic } \\
\text { Fraction } \\
58.52 \% \text {, } \\
\text { Aliphatic } \\
\text { Fraction } \\
73.65 \% \text {, } \\
\text { Asphaltene } \\
28.84 \% \text {, Resin } \\
16.85 \%\end{array}$ & {$[12]$} \\
\hline $\begin{array}{l}\text { Oleophilic } \\
\text { fertilizer }\end{array}$ & $\begin{array}{l}\text { Petroleum, } 2500 \\
\mathrm{mg} / \mathrm{kg}\end{array}$ & 38-days & $80 \%$ & {$[6]$} \\
\hline $\begin{array}{l}\text { Organic } \\
\text { solid waste } \\
\text { of soycake }\end{array}$ & Diesel, $5 \%$ w/w & 126-days & $81 \%$ & {$[41]$} \\
\hline $\begin{array}{l}\text { Microbial } \\
\text { consortium }\end{array}$ & $\begin{array}{l}\text { Crude oil, } 5000 \\
\mathrm{mg} / \mathrm{kg}\end{array}$ & 40-days & $64.4 \%$ & {$[42]$} \\
\hline
\end{tabular}


Fig. 2 shows the comparison between 3 strategies of diesel oil contaminated soil. The highest removal efficiency is $96.6 \%$ after final 90 days in the technology which uses Ottawa sand as bulking agent, poultry and cow manure as nutrient and microbial inoculum. Other two method uses organic solid waste of soy cake, sewage sludge and chemical additives. So, the interaction between bulking agent, microbial community and nutrient can be an important concern to achieve greater removal efficiency within less time period.

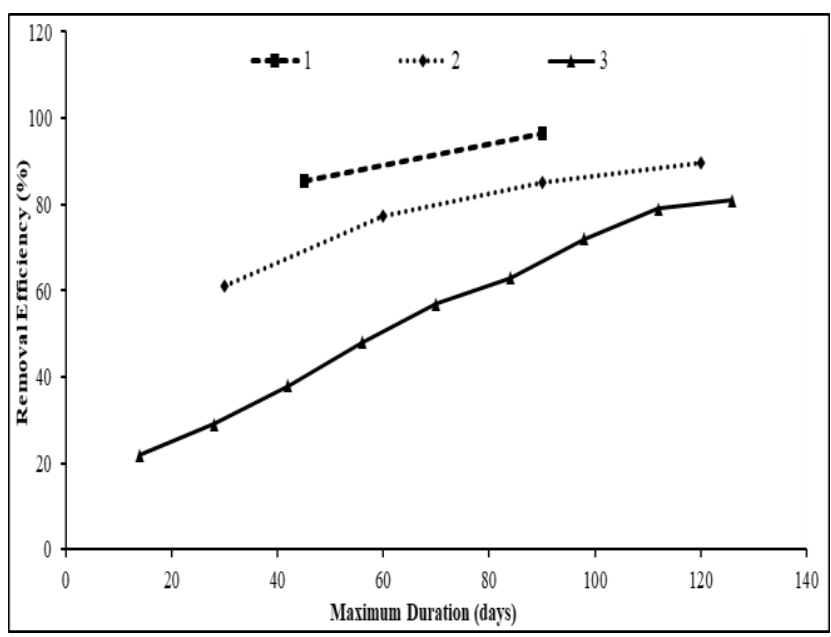

Fig. 2. Removal Efficiency vs Maximum Duration for Diesel Oil Contaminated Soil of three Strategies. Data for 1, 2, 3 from $[10,40,41]$.

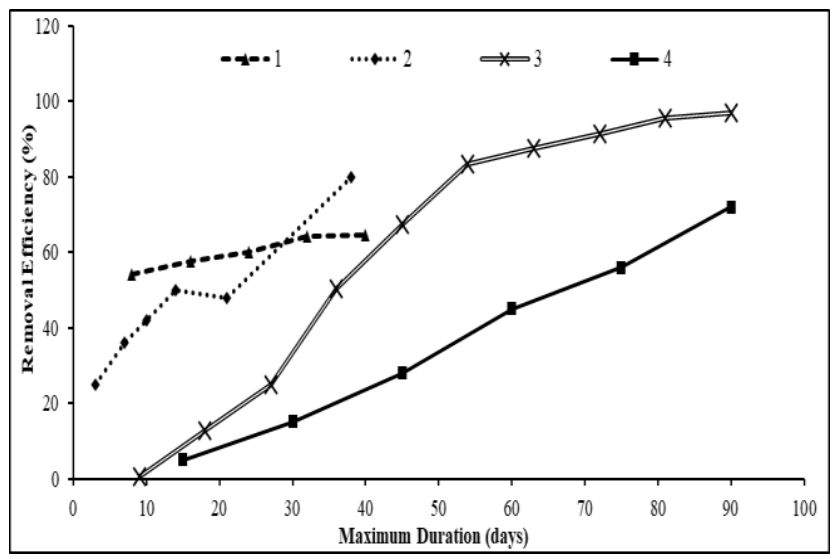

Fig. 3. Removal Efficiency of Total Petroleum Hydrocarbon vs Maximum Duration of four Strategies. Data for 1, 2, 3, 4 from $[3,6,38,42]$.

Fig. 3 represents the comparison between the removal efficiencies of total petroleum hydrocarbon in 4 strategies of bioremediation. Highest removal efficiency is $96.93 \%$ which is for bioremediation method carried out with two hydrocarbon clastic bacterial isolates and 10 stages of 90 days duration in a crude oil bottom tank sludge contaminated soil. Removal efficiency with 4 stages of 40 days period in crude oil contaminated soil is $64.4 \%$ which is lowest among these four methods. So the amount of stages and duration of test involved in a specific bioremediation method can play a significant role to remove oil pollutants.

There is a comparison between maximum removal efficiency of TPH (Total petroleum hydrocarbon), aliphatic fraction, aromatic fraction, asphaltene, asphaltene combined with NSO (nitrogen, sulphur, and oxygen containing compound) and resin in 4 different methods shown in Figure 4. All of these method were carried out for 1 year or more than 1 year.
Aliphatic fraction removal efficiency is highest in all four cases. Resin and asphaltene which are complex compound has the lowest removal efficiency as it take larger time to break down than other compound. If asphaltene is combined with NSO, its removal efficiency as well as overall efficiency will be increased. In maximum cases, treated mechanism was found to be more effective than control mechanism.

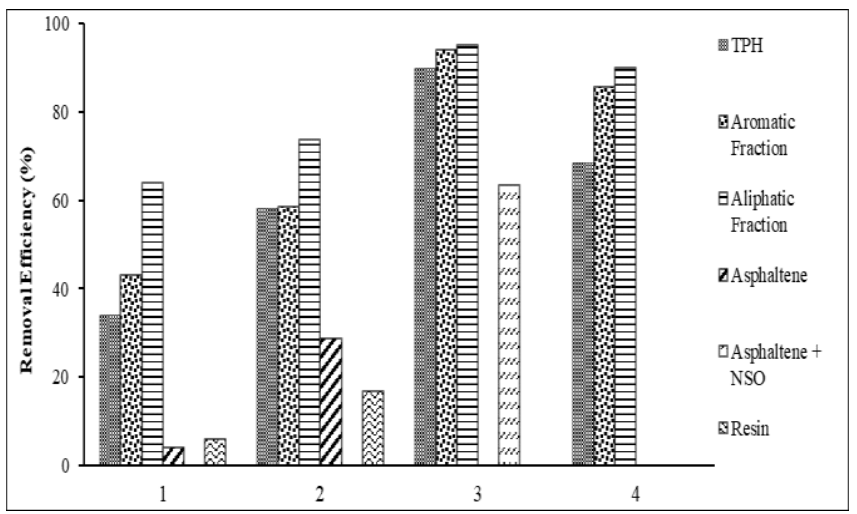

Fig. 4. Removal Efficiency of Total Petroleum Hydrocarbon with Different Fraction of four Strategies. Data for 1, 2, 3, 4 from $[4,12,37,39]$.

\section{Conclusion}

Bioremediation is considered as principal natural process to remove the petroleum hydrocarbon pollutants from the environment in the whole world. Factors which affect bioremediation technology should be kept favorable to carry out microbial activities for optimal result in this method. It is important to select appropriate combination of different materials such as nutrient, bulking agent, microbial community to remediate soil successfully contaminated with different contaminants. Time duration and stages in a method can affect the removal efficiency significantly and complex compounds in oil pollutant can delay the full reduction of contaminants.

\section{References}

[1] James G. Speight. The chemistry and technology of petroleum. Fuel Process Technol 1982; 5: 325-326.

[2] EIA. Egypt-internationalanalysis- us Energy Information Administration (EIA). 2015.

[3] Mansur AA, Taha M, Shahsavari E, et al. An effective soil slurry bioremediation protocol for the treatment of Libyan soil contaminated with crude oil tank bottom sludge. Int Biodeterior Biodegrad 2016; 115: 179-185.

[4] Minai-Tehrani D, Rohanifar P, Azami S. Assessment of bioremediation of aliphatic, aromatic, resin, and asphaltene fractions of oil-sludge-contaminated soil. Int J Environ Sci Technol 2015; 12: 1253-1260.

[5] Deppe U, Richnow HH, Michaelis W, et al. Degradation of crude oil by an arctic microbial consortium. Extremophiles 2005; 9: 461-470. 
[6] Margesin R, Hämmerle M, Tscherko D. Microbial activity and community composition during bioremediation of diesel-oil-contaminated soil: Effects of hydrocarbon concentration, fertilizers, and incubation time. Microb Ecol 2007; 53: 259-269.

[7] Yuniati MD. Bioremediation of petroleumcontaminated soil: A Review. IOP Conf Ser Earth Environ Sci 2018; 118: 012063.

[8] Beškoski VP, Gojgić-Cvijović G, Milić J, et al. Ex situ bioremediation of a soil contaminated by mazut (heavy residual fuel oil) - A field experiment. Chemosphere 2011; 83: 34-40.

[9] Shabir G, Afzal M, Anwar F, et al. Biodegradation of kerosene in soil by a mixed bacterial culture under different nutrient conditions. Int Biodeterior Biodegrad 2008; 61: 161-166.

[10] Ayobamidele Philip A. Bioremediation of Diesel Contaminated Soil Using Biostimula Tion, Bioaugmentation and Bulking Agents. Memorial University of Newfoundland, 2005.

[11] CCME. Canada-wide Standard for Petroleum Hydrocarbons in Soil 2008 Report.doc. 2008.

[12] Liu W, Luo Y, Teng Y, et al. Bioremediation of oily sludge-contaminated soil by stimulating indigenous microbes. Environ Geochem Health 2010; 32: 23-29.

[13] Gallego JL., Loredo J, Llamas J., et al. Bioremediation of diesel-contaminated soils: Evaluation of potential in situ techniques by study of bacterial degradation. Biodegradation 2001; 12: pp 325-335.

[14] Ubani O, Atagana IH, Thantsha SM. Biological degradation of oil sludge: A review of the current state of development. African J Biotechnol 2013; 12: 6544-6567.

[15] Leung M. Bioremediation: techniques for cleaning up a mess. J Biotechnol 2004; 2: 18-22.

[16] Mary Kensa V. Bioremediation - An overview. J Ind Pollut Control 2011; 27: 161-168.

[17] Boettcher G, Nyer EK, Palmer PL. Treatment Technology. Second. CRC Press, 2001.

[18] Kim SJ, Choi DH, Sim DS, et al. Evaluation of bioremediation effectiveness on crude oil-contaminated sand. Chemosphere 2005; 59: 845-852.

[19] Atlas RMM. Microbial degradation of petroleum hydrocarbons: an environmental perspective. Microbiol Rev 1981; 45: 180-209.

[20] Azubuike CC, Chikere CB, Okpokwasili GC. Bioremediation techniques-classification based on site of application: principles, advantages, limitations and prospects. World J Microbiol Biotechnol 2016; 32: 1-18.

[21] Michels J, Track T, Gehrke U, et al. Leitfaden Biologische Verfahren zur Bodensanierung. Gesellschaft für Chem Tech und Biotechnol eV.
[22] Das N, Chandran P. Microbial Degradation of Petroleum Hydrocarbon Contaminants: An Overview. Biotechnol Res Int 2011; 2011: 1-13.

[23] Van Hamme JD, Singh A, Ward OP. Recent Advances in Petroleum Microbiology Recent Advances in Petroleum Microbiology. Microbiol Mol Biol Rev 2003; 67: 503-549.

[24] Atlas RM. Effects of temperature and crude oil composition on petroleum biodegradation. Appl Microbiol 1975; 30: 396-403.

[25] Kosaric N. Biosurfactants and their applications for soil bioremediation. Food Technol Biotechnol 2001; 39: 295-304.

[26] Angelidaki I, Mogensen AS, Ahring BK. Degradation of organic contaminants found in organic waste. Biodegradation 2000; 11: 377-383.

[27] Ward O, Singh A, Van Hamme J. Accelerated biodegradation of petroleum hydrocarbon waste. $J$ Ind Microbiol Biotechnol 2003; 30: 260-270.

[28] Strbak L. In Situ Flushing with Surfactants and Cosolvents. USEPA Publ 2000; 1-36.

[29] Thomas, Norris, Brown, et al. Handbook of Bioremediation. CRC Press, 2018.

[30] Leahy JG, Colwell RR. Microbial degradation of hydrocarbons in the environment. Microbiol Rev 1990; 54: 305-315.

[31] Vincent M. Microbial Bioremediation of Polycyclic Aromatic Hydrocarbons (PAHs) in Oily Sludge Wastes. EngIastateEdu 2005; 1-13.

[32] Cunningham CJ, Philip JC. Comparison of Bioaugmentation and Biostimulation in Ex Situ Treatment of Diesel Contaminated Soil. L Contam Reclam 2000; 8 (4): 261-270.

[33] Rhykerd RL, B. Crews KJ, Mcinnes, et al. Impact of Bulking Agents, Forced Aeration and Tillage on Remediation of Oil-Contaminated Soil. Bioresour Technol 1999; 67: 279-285.

[34] Díaz E. Bacterial degradation of aromatic pollutants: A paradigm of metabolic versatility. Int Microbiol 2004; 7: $173-180$.

[35] Husesemann MH. Guildlines for the land-treating petroleum hydrocarbon contaminated soils. $J$ Soil Contam 1994; 3 (3): 299-318.

[36] Wong JWC, Fang M, Zhao Z, et al. Effect of Surfactants on Solubilization and Degradation of Phenanthrene under Thermophilic Conditions. J Environ Qual 2004; 33: 2015.

[37] Wang S, Wang X, Zhang C, et al. Bioremediation of oil sludge contaminated soil by landfarming with added cotton stalks. Int Biodeterior Biodegrad 2016; 106: $150-156$. 
[38] Vasudevan N, Rajaram P. Bioremediation of oil contaminated soil. Int Biodeterior Biodegradation 2000; 46: $29-36$.

[39] Mishra S, Jyot J, Kuhad RC, et al. Evaluation of Inoculum Addition to Stimulate in Situ Bioremediation of Oily-Sludge-Contaminated Soil. Appl Environ Microbiol 2001; 67: 1675-1681.

[40] Jakubauskaite V, Zukauskaite A, Kryzevicius Z, et al. Bioremediation of the soil contaminated with petroleum oil products using sewage sludge. Acta Agric Scand Sect B Soil Plant Sci 2016; 66: 664-670.
[41] Dadrasnia A, Agamuthu P. Biostimulation and monitoring of diesel fuel polluted soil amended with biowaste. Pet Sci Technol 2014; 32: 2822-2828.

[42] Shen W, Zhu N, Shang R, et al. Ecotoxicity monitoring and plant bioindicators screening of oilcontaminated soil during bioremediation. Huanjing Kexue Xuebao/Acta Sci Circumstantiae 2016; 36: 232 242. 